\title{
EFFECT OF RISING WEAR-RESISTANCE BY PLASMA TREATMENT OF CARBURIZED STRUCTURAL STEEL
}

\author{
Cheylyakh Y.A. ${ }^{1}$, Cheiliakh O.P. ${ }^{2}$, Mak-Mak N.E. ${ }^{2}$, Kazumichi Sh. ${ }^{3}$ \\ ${ }^{1}$ Ilyich Iron and Steel Works PJSC, Mariupol', Ukraine \\ ${ }^{2}$ Priazovskiy State Technical University, Mariupol', Ukraine \\ ${ }^{3}$ Muroran Institute of Technologies, Muroran, Japan
}

\begin{abstract}
Plasma treatment, owing to high concentrated rapid heating, ensures microstructure dispersion and creates the possibility of the formation of meta-stable phase-structural austenite modifications in carbonized surface layers of metal parts. The objective of the work is to investigate opportunities for strengthening and improving wear resistance of structural carbonized steel by modifying the amount and meta-stability of austenite, by means of plasma treatment.

Metallographic and X-ray research was used, as well as measurements of hardness and micro-hardness toughness. Wear resistance was tested at dry friction of metal sliding against metal.

Following plasma treatment with micro-fusion $\left(\mathrm{T} \approx 1500^{\circ} \mathrm{C}\right)$, there happens to be an increase in wear resistance of 18ХГТ steel, when fine-crystalline martensite dispersed with carbonized particles is observed at a small amount of residual austenite $(20-25 \%)$.

An effect of self-strengthening at the process of testing was reached due to the realization of Deformation Induced Martensity $\gamma$ ret. $\rightarrow \alpha^{\prime}$ Transformation at wear (DIMTW).
\end{abstract}

Keywords: Carbonization, plasma, micro-fusion, treatment, residual austenite, meta-stability, transformation, martensite, wear resistance.

\section{Introduction}

The problem of increasing wear resistance and service lives of carbonized machine parts remains a vital one. The applied methods of heat treatment are restricted to quenching, usually from $780-800{ }^{\circ} \mathrm{C}$ temperatures, ensuring obtaining of the structure of martensite and cementite at minimal amount of residual austenite $\left(A_{\text {ret. }}\right)$ [1]. Presence of $A_{\text {ret. }}$ in the structure is considered harmful in the majority of works $[1,2]$. Only some works [3-5] indicate its positive influence upon wear resilience of carbonized steels.

Plasma treatment is characterized by highconcentrated heating at a high rate [8], it giving an opportunity of influencing upon the degree of solving of excess carbides, present in carbonized layers. As a result of their solution and dispersing of the microstructure opportunities of modifying the amount of $A_{\text {ret. }}$. and the degree of its meta-stability emerge [5-7], thus making it possible to control the properties of carbonized steels However, the problem of application of plasma treatment for strengthening of carbonized layers has not been thoroughly investigated yet

The objective of the work is to investigate the opportunities of additional strengthening and improving wear resistance of carbonized steel by regulating the amount of austenite, by means of plasma treatment.

C) Cheylyakh Y.A., Cheiliakh O.P., Mak-Mak N.E., Kazumichi Sh., 2016

\section{New approaches of phase-structural modification of saturated layer. Materials and methods of investigation}

For specified properties of saturated layers, irrespective of a method of TChT the final heat treatment, forming most appropriate phase-structural state seems to be of a paramount importance. The bulk of contemporary approaches to formation of phase-structural state of the surface layer presume obtaining a structure in a form of a mixture of highcarbon or high-nitrogen quenching martensite and particles of hard phases - carbides, nitrides, carbon borides et al. Retained austenite $\left(\mathrm{A}_{\mathrm{ret}}\right)$ is considered to be undesired in many cases, as it undermines hardness, fatigue durability and wear resistance under conditions of sliding friction. That is why quenching, normally, from $t_{3}=\mathrm{A}_{\mathrm{c} 1}+30 \ldots 50^{\circ} \mathrm{C}$ temperatures is specified as a standard mode of final heat treatment, or quenching with sub-cooling from the temperatures of carburizing (nitro-carburizing) up to these temperatures in oil and then a lowtemperature tempering $\left(180 \ldots 220^{\circ} \mathrm{C}\right)$.

Still, in some investigation, (including those performed at SHEI "PSTU") indicate a positive influence of a presence of certain amounts and a degree of metastability of $A_{\text {ret }}$ for improvement in mechanical and functional properties of saturated layers. Its improvement is possible only at optimum relationship between 
quenching martensite, carbides and $\mathrm{A}_{\text {ret }}$ and also at some degree of metastability of the latter, it depending upon the specified properties, operation conditions (testing conditions) of parts. So, retaining of $\mathrm{A}_{\text {ret }}$ together with martensite and particles of hard phases can be described as a new approach to developing of promising TChT technologies.

Such treatment should be aimed at optimization of the phase content of the saturated layers and the degree of metastability of $A_{\text {ret }}$ DIMT of which ensures the effect of self-strengthening in the process of testing and operation, it becoming an additional factor of increasing mechanical and operational properties. To do it is necessary to utilize all possible mechanisms and instruments of stabilization, or, otherwise, destabilization of austenite.

To the factors of stabilization of austenite, promoting growth of its amount and the degree of its stability at loading to $\gamma_{r e t} \rightarrow \alpha^{\prime}$ DIMT the following ones belong:

- thermal stabilization, due to relaxation of micro-stresses and blocking of dislocations by interstitial atoms;

- mechanical stabilization, due to increase of density of dislocations in austenite, under the action of plastic deformation, like at TMT or surface plastic deformation (SPD);

- chemical stabilization, owing to an increase of the content of austenite-forming and other elements (carbon, nitrogen, chromium, manganese, nickel, silicon etc.), decreasing $\mathrm{M}_{\mathrm{s}}$ point;

- high-energy stabilization, caused by application to the material high concentrations of thermal energy, like at laser, plasma or electron-beam action;

- kinetic one, due to the peculiarities of the kinetics an the mechanism of phase transformations in saturated layers, like at bainite or isothermal martensite transformations;

- structural stabilization, due to smaller grain size of austenite.

Factors of austenite destabilization in saturated layers, promoting reduction of its content and activation of $\gamma_{r e t} \rightarrow \alpha^{\prime}$ DIMT are the following:

- chemical destabilization, connected with an decrease of concentration of austenite-forming $(\mathrm{C}$, $\mathrm{N}, \mathrm{Ni}, \mathrm{Mn}, \mathrm{Cu}, \mathrm{Co})$ and other alloying elements $(\mathrm{Cr}$, $\mathrm{Si}$ ) in austenite, it causing ah increase of $\mathrm{M}_{\mathrm{s}}$ point and promotes reduction of its amount in the structure and activates $\gamma_{\text {ret }} \rightarrow \alpha^{\prime}$ DIMT;

- mechanical destabilization, due to an increase of the level of internal stresses, like at plastic de- formation;

- structural destabilization, caused by an increase in austenite grain and reduction of dislocations density;

- action of the magnetic field, stimulating martensite transformation, owing to a raise of $\mathrm{M}_{\mathrm{s}}$ point.

Carburizing steel $18 \mathrm{CrMnTi}$ was performed in a box furnace in production conditions machine "MAGMA" carburizer solid at temperatures 920 $950{ }^{\circ} \mathrm{C}$ for $12-14$ hours, cooled in a box. Plasma hardening was performed using plasmatron "PPU 004" indirect action, designed at SHEI "PSTU", using argon as the plasma gas. Treatment regimens are shown in table).

Operation parameters of plasma treatment of $18 \mathrm{CrMnTi}$ stee

\begin{tabular}{|c|c|c|c|c|c|}
\hline $\begin{array}{c}\text { № } \\
\text { Mode } \\
\text { number }\end{array}$ & $\begin{array}{l}\text { Cur- } \\
\text { rent } I \text {, } \\
\text { A }\end{array}$ & $\begin{array}{l}\text { Gas con- } \\
\text { sumption } \\
Q, \mathrm{~m}^{3} / \mathrm{s}\end{array}$ & $\mathrm{T},{ }^{\circ} \mathrm{C}$ & \begin{tabular}{|l|} 
Rate of \\
motion \\
$V, \mathrm{~m} / \mathrm{h}$
\end{tabular} & $\begin{array}{l}\text { Degree of plas- } \\
\text { ma action }\end{array}$ \\
\hline 1 & \multirow{5}{*}{300} & 12 & $\begin{array}{l}800- \\
900\end{array}$ & 62,5 & $\begin{array}{l}\text { heating without } \\
\text { melting }\end{array}$ \\
\hline 2 & & 12 & $\begin{array}{l}1200- \\
1400 \\
\end{array}$ & 50 & $\begin{array}{c}\text { heating without } \\
\text { melting }\end{array}$ \\
\hline 3 & & 12 & 1500 & 33,3 & micro-melting \\
\hline 4 & & 12 & 1600 & 25 & medium melting \\
\hline 5 & & 12 & $>1700$ & 8,13 & macro-melting \\
\hline
\end{tabular}

\section{Results of research and their discussion}

Application of rapid ways of high - energy surface heating, like, for example, with high frequency currents (HFC), plasma jets, laser or electron beams opens additional opportunities of strengthening of carburized layers. If plasma action is used for strengthening, then, heating to different temperatures should be considered, it depending upon the value of heat input and is regulated by the parameters of plasma treatment.

Plasma heating of steel $18 \mathrm{CrMnTi}$ was carried out without melting at different temperatures within the range from 800 to $1300^{\circ} \mathrm{C}$ and the melting of the surface layer of varying degrees: micro-melting ( $t=$ $\left.=1400 \ldots 1500^{\circ} \mathrm{C}\right)$, the average melting $(t=$ $\left.=1500 \ldots 1600^{\circ} \mathrm{C}\right)$ and the macro-melting $(t>$ $>1600^{\circ} \mathrm{C}$ ) which regulated by the speed of vertical movement of the plasma jet relative to a horizontal surface of the samples with speeds ranging from 81 to $625 \mathrm{~mm} / \mathrm{min}$. After plasma exposure natural cooling of the strengthened areas, due to heat conductivity occurred. 
After plasma quenching from relatively low temperatures $\left(800 \ldots 900^{\circ} \mathrm{C}\right)$ in the carburized layer a significantly greater amount of $\mathrm{A}_{\text {ret }}$ in carburized layer (Fig. 1, a) was observed apart of martensite and carbides. It is located in bright microdomains between martensite needles. According to the depth of the hardened layer the amount of $\mathrm{A}_{\text {ret }}$, decreased and martensite is characterized by high dispersion and hardness.

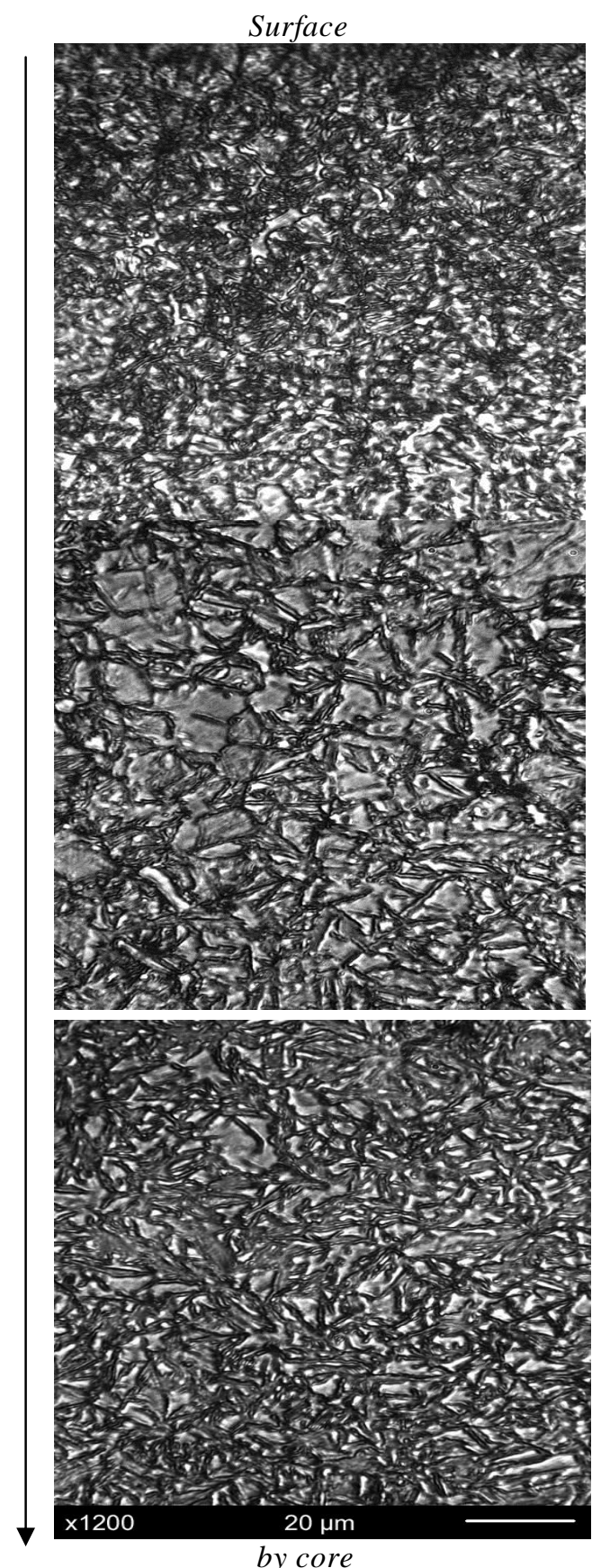

a)
After plasma quenching from higher temperatures $\sim 1200 \ldots 1300^{\circ} \mathrm{C}$ microstructure of the carburized layer in steel $18 \mathrm{CrMnTi}$ was characterized by greater dispersion of the carbide phase and sites $\mathrm{A}_{\text {ret }}$, which were evenly distributed over the depth of the layer (Fig. 1, b). This is due to the start of dissolution of cementite particles in the austenite, but some of them are retained in the structure.

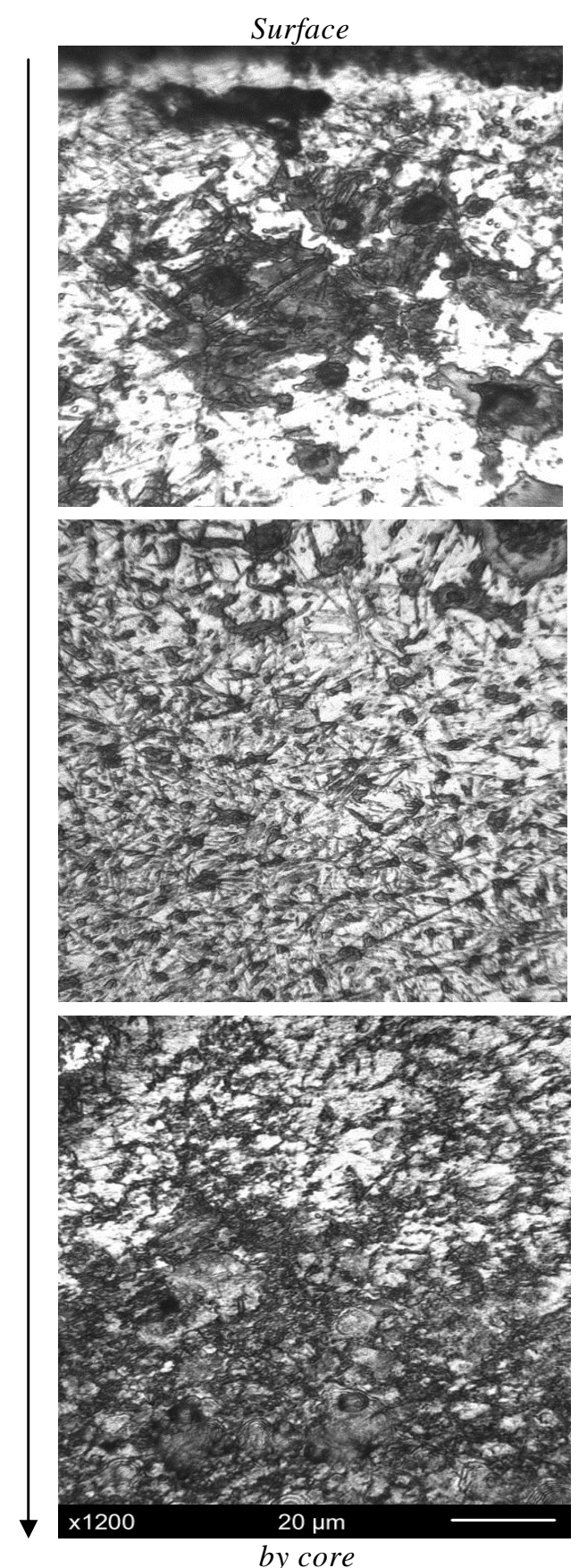

b)

a) $800 \ldots 900^{\circ} \mathrm{C}$; b) $1200 \ldots 1400^{\circ} \mathrm{C}$

Fig. 1. Microstructure of carburized steel $18 \mathrm{CrMnTi}$ after plasma hardening at different temperatures 
Gradually, the structure becomes a sorbite-like mixture. As a result of this treatment, the hardness of the hardened surface layer increased slightly from HRA 72 during quenching from $800 \ldots 900^{\circ} \mathrm{C}$ to HRA 74 (Fig. 2).

After plasma treatment with micro-melting at temperatures of $\sim 1500^{\circ} \mathrm{C}$, the structure of the hardened layer varies considerably in the surface zone (Fig. 3, a). A lot of cementite particles and martensite needles and a small amount of $A_{\text {ret }}$ are observed. As the distance from the surface to the core increases the amount of $\mathrm{A}_{\text {ret }}$ and cementite gradually decreases while quenching martensite hardening increases. Further hardening depth structure passes into the mixture of troostomartensite and cementite.

As a result, the plasma treatment at about $1500^{\circ} \mathrm{C}$ leads to increase of the hardness up to HRA 80. It can be explained by disperse structure and the increase of degree of solid solution saturation with carbon.

With increasing temperatures of plasma heating $\left(\sim 1600^{\circ} \mathrm{C}\right.$ and $\left.>1700^{\circ} \mathrm{C}\right)$, a significant macromelting becomes obvious. The microstructure of the remelted surface layer consists of rather large needles of martensite and cementite particles on the background of $\mathrm{A}_{\text {ret }}$ (Fig. 3, b). This area is quite ex- tended, gradually transformed into fine-crystalline mixture of $\left(\mathrm{M}+\right.$ cementite $\left.+\mathrm{A}_{\text {ret }}\right)$.

Coarsely grained rough-crystal structure corresponds to the zone of remelting; fine-grained structure corresponds to plasma heating zone (without melting), followed by a narrow transition zone from the plasma hardened metal to unhardened metal.

With increasing temperature plasma heating hardness of reinforced carburized layer varies along the curve with a maximum (HRA 80), which corresponds to heating of $\sim 1500^{\circ} \mathrm{C}$, then at temperatures up to about $1700^{\circ} \mathrm{C}$ hardness is reduced to HRA 60 that can be attributed to an increase in the content of $\mathrm{A}_{\text {ret. }}$.

Thus, the plasma treatment of carburized steel $18 \mathrm{CrMnTi}$, depending on the heat input and a heating temperature can significantly change the microstructure of the saturated layer, which achieves a superior dispersibility, with different amount of increased content $\mathrm{A}_{\text {ret. }}$.

It was found that different quantity of $\mathrm{A}_{\text {ret }}$ and its dispersion structure determining the degree of stability and its ability to deformation $\gamma_{\text {ret }} \rightarrow \alpha^{\prime}$ DIMT in wear (DIMTW), which significantly affects the performance characteristics [5].

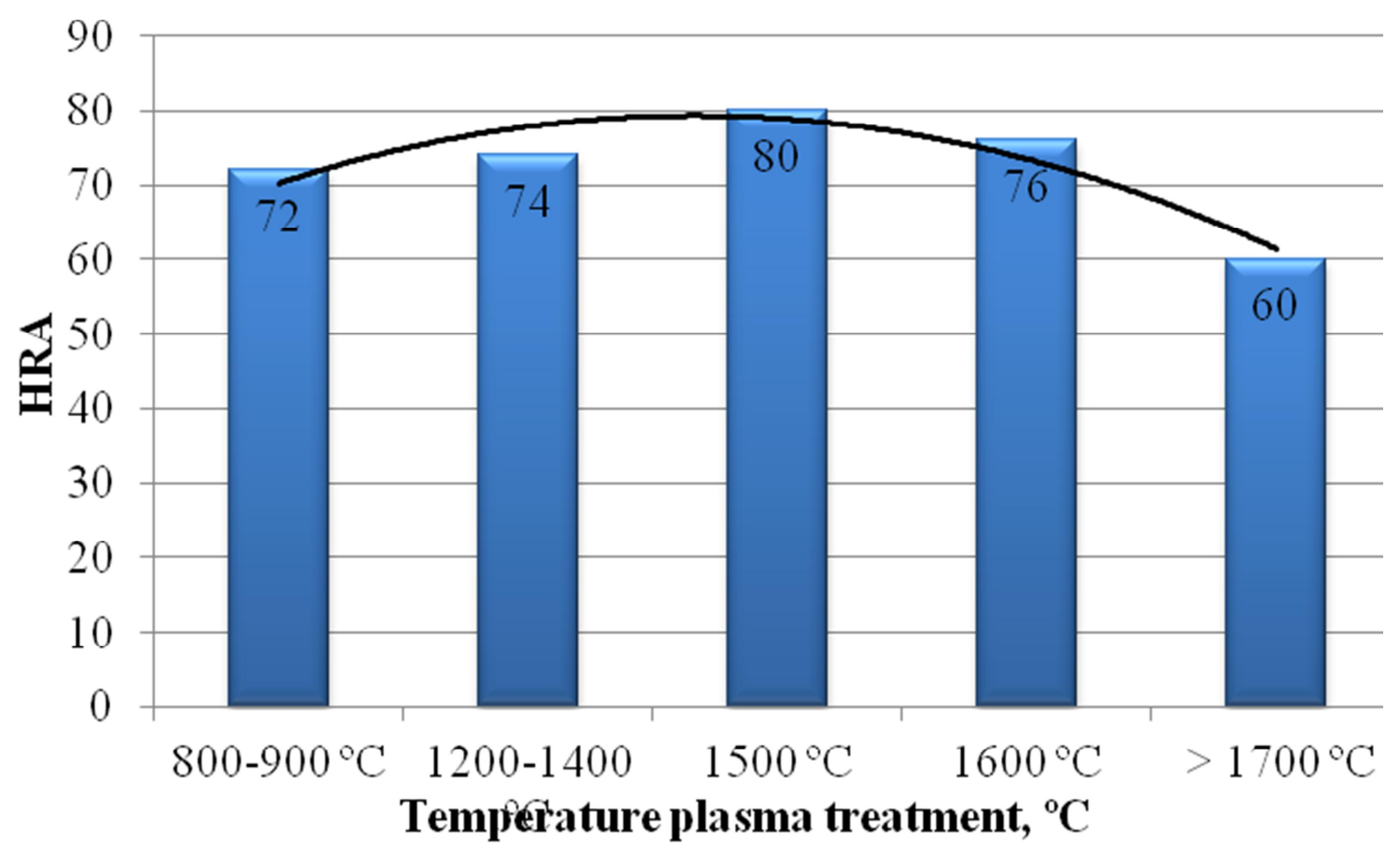

Fig. 2. Effect of plasma treatment temperature on hardness carburized steel $18 \mathrm{CrMnTi}$ 


\section{ТЕХНОЛОГИИ ОБРАБОТКИ МАТЕРИАЛОВ}

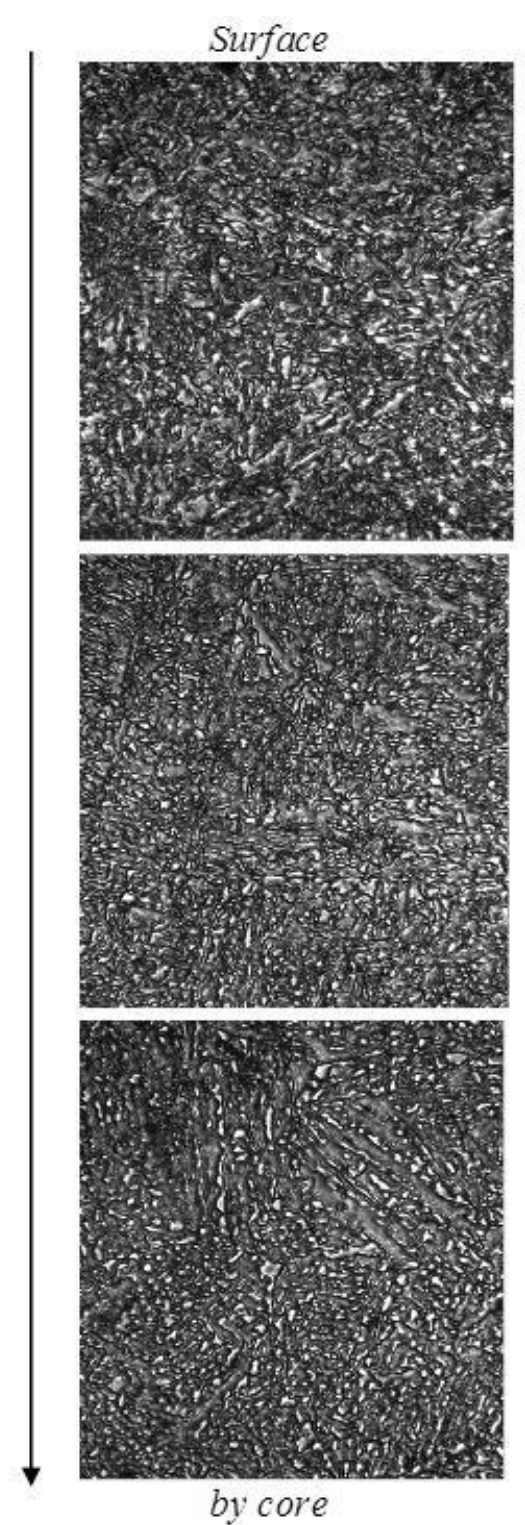

a)

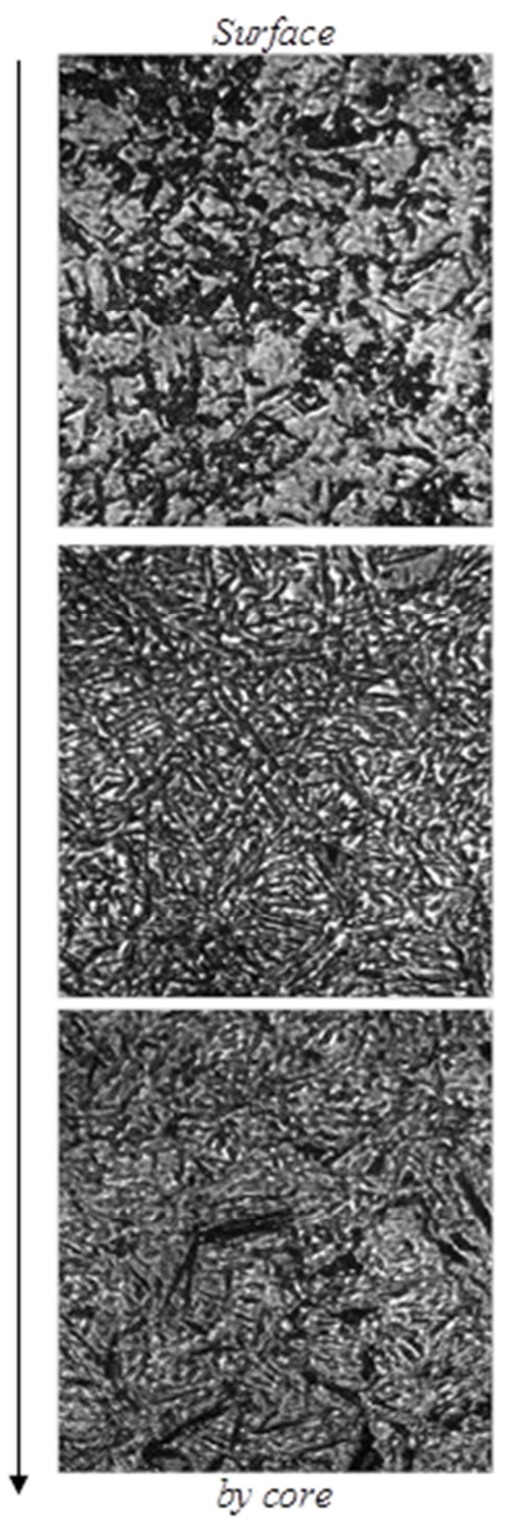

b)

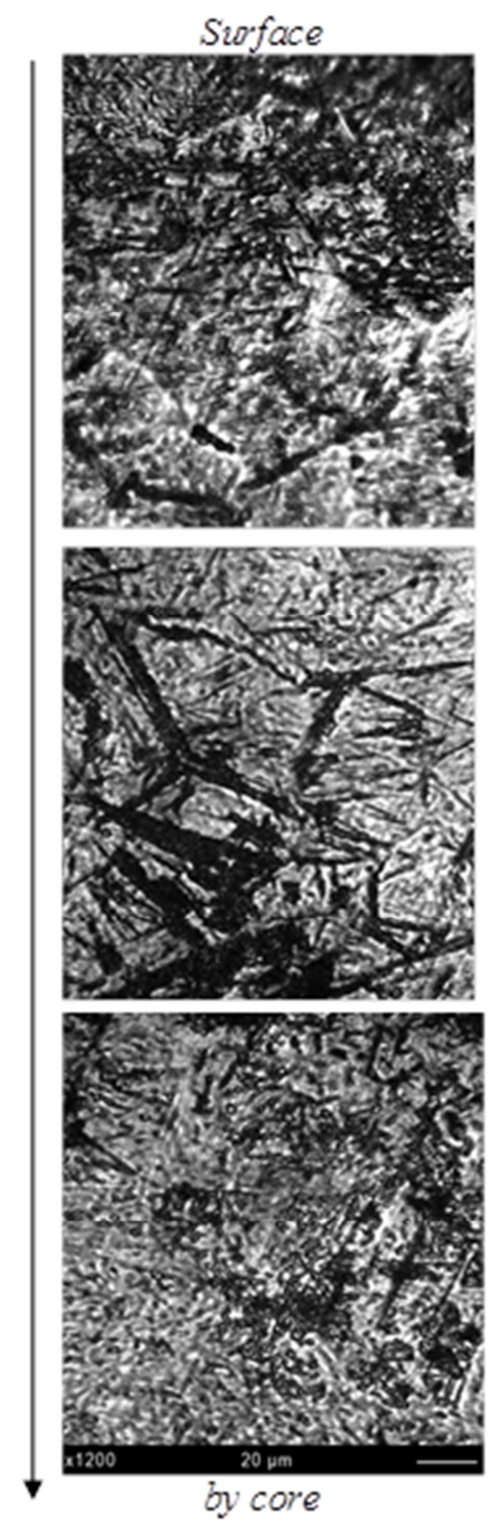

c)

a) $1500^{\circ} \mathrm{C}$; b) $\left.1600^{\circ} \mathrm{C}, \mathrm{c}\right)>1700^{\circ} \mathrm{C}$

Fig. 3. Microstructure of carburized steel $18 \mathrm{CrMnTi}$ after plasma hardening at temperatures

Experimental test results for dry sliding wear by scheme "metal-metal" are shown in Fig. 4. Depending on the temperature of the plasma heating changed the relative wear resistance according to the curve with a maximum $\varepsilon=3.7$ (similar hardness change), which corresponds to micro-melting at $1500^{\circ} \mathrm{C}$. This is explained by obtaining the most dispersed mixture of quenching martensite, cementite with a high content of metastable $\mathrm{A}_{\text {ret }}$.

Developing $\gamma_{r e t} \rightarrow \alpha^{\prime}$ DMTW itself was accompanied with additional hardening of a thin surface layer in the process of wear, as formed by the test deformation martensite has a higher dispersion and hardness than that of quenching martensite. An additional and very significant contribution to the improvement of wear resistance is given by $\gamma_{\text {ret }} \rightarrow \alpha^{\prime}$ DMTW that provides the effect of strain hardening of the surface layer itself. Note that DMTW accompanied with micro-stressing relaxation is an effective mechanism for redistribution and absorption of input mechanical energy of friction and wear.

The lowest values of $\varepsilon=1.6$ correspond to the plasma remelting at temperatures $>1700^{\circ} \mathrm{C}$, which is associated with the formation of coarse crystalline structure. 


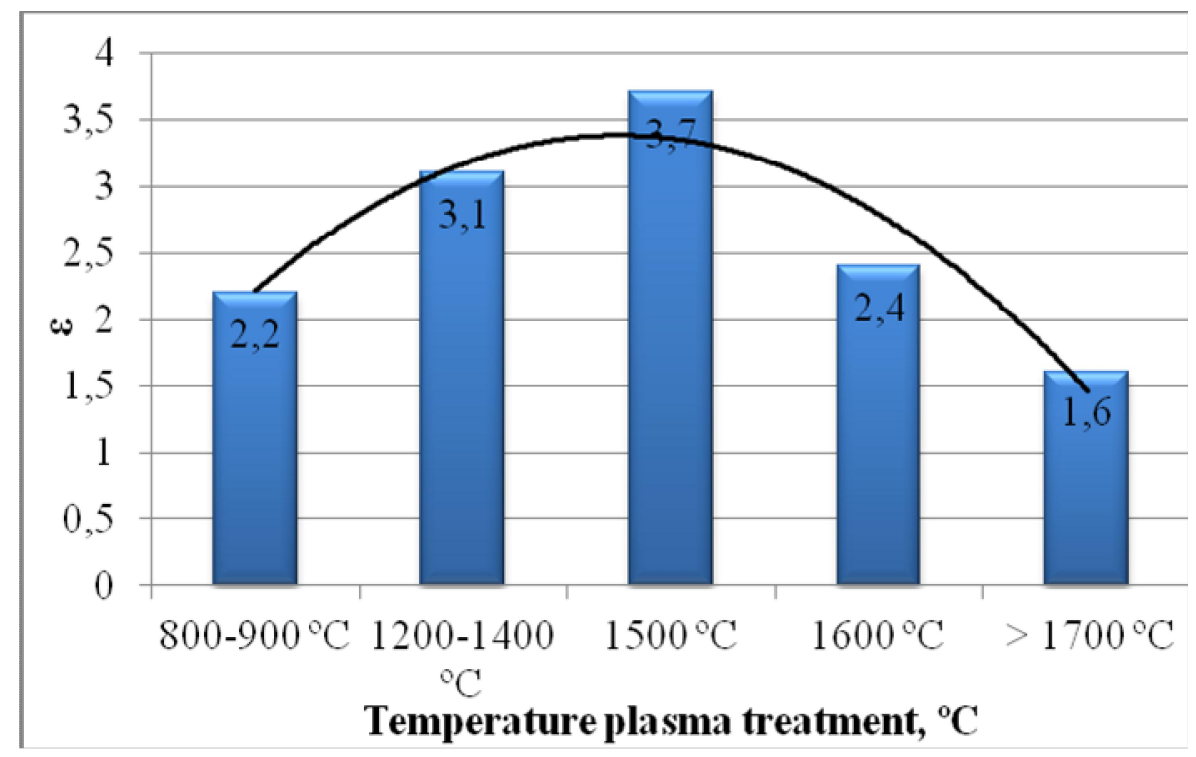

Fig. 4. Effect of plasma treatment temperature on the relative wear resistance of carburized steel $18 \mathrm{CrMnTi}$

Thus as the result of plasma strengthening of the carburized steel surface layer of $18 \mathrm{CrMnTi}$ grade by means of controlled heat input values of the plasma jet, provides differential phase-structural states with different content and the degree of retained austenite metastability along with the presence of hard phases quenching martensite and carbides.

Deformation $\gamma_{r e t} \rightarrow \alpha^{\prime}$ martensite transformation under wear makes an additional contribution into strengthening and improving of wear resistance of carburized steel $18 \mathrm{CrMnTi}$ if optimum microstructure (after plasma quenching with heating temperatures at $\sim 1200 \ldots 1400^{\circ} \mathrm{C}$ and $\sim 1500^{\circ} \mathrm{C}$ ) is obtained.

\section{Conclusions:}

1. As the result of plasma strengthening of the surface carburized steel layer of $18 \mathrm{CrMnTi}$ grade by means of controlled heat input values of the plasma jet, provided there were differential phase-structural states with different amounts of content and the degree of residual austenite meta-stability along with the presence of solid phases - quenching martensite and carbides.

2. Significant changes in microstructure occurred under the influence of the microstructure of plasma heat treatment modes, determining formation of the mechanical properties of carburized steel $18 \mathrm{CrMnTi}$. Depending on the temperature of the plasma exposure to the relative hardness and durability of the hardened surface layer varies along a curve with a peak corresponding to heating of about $1500^{\circ} \mathrm{C}$.

3. Additional contribution into strengthening and improving of wear resistance of carburized steel $18 \mathrm{CrMnTi}$ if optimum microstructure (plasma after quenching with heating temperatures at about $\approx$ $1200-1400^{\circ} \mathrm{C}$ and $1500^{\circ} \mathrm{C}$ ) introduces strain $\gamma_{\text {res }} \rightarrow \alpha^{\prime}$ martensite transformation at wear.

\section{References}

1. Gurevich B.G., Yur'ev S.F. O roli ostatochnykh napryazhenii v povyshenii predela vynoslivosti stali pri khimiko-termicheskoy obrabotke [On the role of residual stresses in raising the fatigue strength of steel during thermochemical treatment]. Moscow: Mashgiz, 1952, pp. 43-63.

2. Assonov A.D. Tekhnologiya termicheskoy obrabotki detaley mashin [Heat treatment of machine parts]. Moscow: Mashinostroenie, 1969, $120 \mathrm{p}$.

3. Malinov L.S., Malinova E.L., Kharlanova E.Ya. Improving the abrasive wear resistance of 18KhGT and 12KhNZA carbonized steels due to the creation of metastable austenite. Metally [Metals]. 1993, no. 2, pp. 108-111.

4. Geller A.L., Yurko V.N. Residual austenite and wear resistance of alloyed carbonized steels. Izv. VUZov. Chernaya metallurgiya [Proceedings of Russian Universities. Nonferrous metallurgy]. 1991, no. 6, pp. 66-69.

5. Cheylyakh A.P. Ekonomnolegirovannye metastabil'nye splavy $i$ uprochnyayushchie tekhnologii [Lean metastable alloys and hardening techniques]. Mariupol': PGTU, 2009, 483 p.

6. Cheiliakh A.P., Cheiliakh Y.A., Karavaieva N.E. et al. Development of innovative ways of surface hardening by means of the creation of wear-resistant layers with metastable structure, strengthening at wear. Termoobrabotka metallov [Heat Treatment of Metals]. 2014, no. 143, pp. 35-36.

7. Cheiliakh A.P., Cheiliakh Y.A., Karavaieva N.E. et al. Development of innovative ways of surface hardening through the creation of wear-resistant layers with metastable structure, strengthening at wear. Termoobrabotka metallov [Heat Treatment of Metals]. 2014, no 144, pp. 25-26.

8. Samotugin S.S., Leshchinskii L.K. Plazmennoe uprochnenie instrumental'nykh materialov [Plasma treatment of structural materials]. Donetsk : Novyy mir, 2003, 338 p. 


\title{
ЭФФЕКТ ПОВЫШЕНИЯ ИЗНОСОСТОЙКОСТИ
} ЗА СЧЕТ ПЛАЗМЕННОЙ ОБРАБОТКИ НАУГЛЕРОЖЕННЫХ КОНСТРУКЦИОННЫХ СТАЛЕЙ

\author{
Чейлях Я.А., Чейлях А.П., Мак-Мак Н.Е., Казумичи Ш.
}

Аннотация. За счет скоростного нагрева плазменное упрочнение обеспечивает дисперсную микроструктуру и создает возможность образования метастабильного фазоструктурного аустенита в науглероженных поверхностных слоях стальных деталей. Целью настоящей работы является исследование возможностей упрочнения и повышения износостойкости науглероженных конструкционных сталей путем изменения количества и метастабильности аустенита посредством технологии плазменного упрочнения.

Были проведены металлографическое и рентгеновское исследования, произведены замеры твердости, микротвердости и ударной вязкости. Испытание износостойкости производилось трением металла о металл «на сухую».

В результате плазменного упрочнения с микроплавкой $\left(\mathrm{T} \approx 1500{ }^{\circ} \mathrm{C}\right)$ происходит увеличение износостойкости стали марки $18 X Г Т$, когда при небольшом количестве остаточного аустенита (20-25\%) наблюдается мелкокристаллический мартенсит, диспергированный с частицами карбида.

В процессе испытаний эффект самоупрочнения был получен благодаря осуществлению наведен-ного деформацией мартенситного $\gamma$ ret. $\rightarrow \alpha^{\prime}$-превращения при износе.

Ключевые слова: науглероживание, плазма, микросплавление, обработка, остаточный аустенит, метастабильность, превращение, мартенсит, износостойкость.

Эффект повышения износостойкости за счет плазменной обработки науглероженных конструкционных сталей / Чейлях Я.А., Чейлях А.П., Мак-Мак Н.Е., Казумичи Ш. // Вестник Магнитогорского государственного технического университета им. Г.И. Носова. 2016. Т.14. №2. С. 76-82. doi:10.18503/1995-2732-2016-14-2-76-82

Cheylyakh Y.A., Cheiliakh O.P., Mak-Mak N.E., Kazumichi Sh. Effect of increased wear-resistance by the plasma treatment of carbonized structural steel. Vestnik Magnitogorskogo Gosudarstvennogo Tekhnicheskogo Universiteta im. G.I. Nosova [Vestnik of Nosov Magnitogorsk State Technical University]. 2016, vol. 14, no. 2, pp. 76-82. doi:10.18503/1995-2732-2016-14-2-76-82 